\title{
USE OF BLACK SEED (NIGELLA SATIVA L.) OIL IN THE MANAGEMENT OF HYPERTENSIVE AND HYPERLIPIDEMIC INDIVIDUALS OF DISTRICT MUZAFFARABAD, AZAD KASHMIR, PAKISTAN
}

\author{
HUSSAIN, N. ${ }^{1}$ - MAJID, S. A. ${ }^{1}-$ ABBASI, M. S. ${ }^{2}$ - HUSSAIN, M. A. ${ }^{* 3}$ - REHMAN, K. ${ }^{4}$ \\ KHAN, M. Q. ${ }^{1}-$ DAR, M. E. U. I. ${ }^{1}-$ SHAHEEN, H. ${ }^{1}-$ HABIB, ${ }^{1}{ }^{1}$ \\ ${ }^{I}$ Department of Botany, University of Azad Jammu \& Kashmir \\ Muzaffarabad 13100, Pakistan \\ ${ }^{2}$ Department of Cardiology, Abbass Institute of Medical Sciences \\ Muzaffarabad 13100, Pakistan \\ ${ }^{3}$ Department of Biotechnology, Mirpur University of Science \& Technology (MUST), \\ Mirpur-10250, AJK, Pakistan \\ ${ }^{4}$ Department of Botany, Mirpur University of Science \& Technology (MUST), \\ Mirpur-10250, AJK, Pakistan \\ *Corresponding author \\ e-mail: scholar.altaf@gmail.com \\ (Received 19 $9^{\text {th }}$ Nov 2016; accepted $21^{\text {st }}$ Mar 2017)
}

\begin{abstract}
Hypertension and hyperlipidemia are two main causes of cardiovascular diseases with rapidly increasing pervasiveness worldwide. Complimentary alternative medicines provide an effective choice to these highly prevalent global health issues. Nigella sativa has diverse range of traditional and pharmacological potential with established safety profile. This study was carried out in 163 mildmoderate hypertensive and hyperlipidemic patients. Patients were selected randomly of both genders. The patient's age ranges between 20-65 years. This clinical study was conducted to evaluate the clinical effect of Nigella sativa virgin oil in hypertension and hyperlipidemic patients of the selected region and also assess its antioxidative potential. The results conferred that $N$. sativa has significant $(<0.05)$ effect on controlling hypertension and hyperlipidemia as compared to standards used. Moreover, $N$. sativa conferred excellent antioxidant potential as compared to other commercially available edible oils.
\end{abstract}

Keywords: alternative medicines, pharmacological, antioxidants, virgin oil, edible oils

\section{Introduction}

Hypertension is the major cause of cardiovascular diseases (CVD) which is significantly increasing day by day and according to an estimate by the end of 2025 it will go up to 1.4 billion of the world's adult population (Kearney et al., 2005). Hypertension is defined as a systolic blood pressure greater than $140 \mathrm{mmHg}$ and/or diastolic $90 \mathrm{mmHg}$ or greater, and any record of serum lipid abnormality is defined as hyperlipidaemia. There are number of known cardiovascular disease, renal disease, liver disease, obesity, high cholesterol and stressful conditions; an unknown reasons of high blood pressure (essential hypertension). Hypertension is a silent killer disease as it may go undiagnosed for years and when detected had developed chronic heart disease, cardiovascular disease, diabetes mellitus, renal disease, etc. However, if properly diagnose and treat would reduce the morbidity and mortality (Schuman and Emerson, 1998). Hypertension in long terms impairs the renal function and resulted to failure in 
majority of the cases (Klag et al., 1996) and these all causes cardiovascular complication (Rostand et al., 1991). Clinical studies demonstrated that a reduction in hypertension can control $42 \%$ risk of stroke and $14 \%$ coronary heart disease (Hobbs, 2004). In the struggle of modernization and exposure to globalization the population of low income countries greatly affected their lives to pursue their high living standards. Although some get well succeed status but many deprived in hands of cultural and social adjustments that may cause increase in hypertension. Hypertension has long been thought of Western world disease but now it is equally the part of poor countries. In addition to organic causes lifestyle play major role in this regard. The lifestyle of many people has become more westernized. Several studies hypothesized its contribution to hypertension in urban populations when compared to rural populations ( $\mathrm{Ma}$ et al., 2012). Within the non-communicable diseases hypertension plays leading role posing threats of disabilities (WHO, 2013) and this is because of unawareness to these conditions by a high number of hypertensive individuals (Kayima et al., 2013). In a study of prevalence of hypertension, in low and middle income countries the blood pressure found in more than half of population higher than in US (Fuentes et al., 2000). Although hypertension is the cause of mortality and morbidity in world (Rodger et al., 2004) but stroke in urban East-African countries is five times higher than in Britain (Walker et al., 2000).

Nigella sativa is an annual herb belonging to family Ranunculaceae with huge medicinal potential. Its seeds and seeds extracts has been used medicinally for centuries especially in Mediterranean region, Middle-East and Southeast Asia (Rchid et al., 2004; Najmi, et al., 2008). It has tremendous traditional and pharmacological potential in curing a wide range of ailments particularly hypotension (Aqel, 1992), hypoglycaemia (Bamosa et al., 1997; Meral et al., 2001; Bamosa et al., 2010), oxidative stress (Burits and Bucar, 2000) and cardio protective (Tasawar et al., 2011). N. sativa plant has strong antihypertensive effect that significantly lowered down blood pressure and cholesterol (Dehkordi and Kamkhah, 2008). Reinhart et al. (2008) also reported its hypotensive, hypercholesterolemic, hypoglycaemic and antioxidative activities. $N$. sativa significantly reduces intracellular cholesterol by regulating LDL, HDL and triglycerides blood levels (El-Dakhakhany, 2000). Obesity is the main cause of metabolic syndrome (Vega, 2001). BMI is also an important indicator of metabolic syndrome (Najmi et al., 2008). N. sativa showed a significant reduction in the body weight when administered to a experimental model of rats (Zaoui et al., 2002). More than 100 bioactive compounds had been reported in the $N$. sativa seeds (Ramadan, 2007). The therapeutic potential of medicinal plants is mainly due to the antioxidative properties of some active components (El-Saleh et al., 2004). The seeds of $N$. sativa contains two active components in its oils i.e. Thymoquinone and dihydrothymoquinone, revealed enormous potential of free radical scavenging capabilities (Khalife and Lupidi, 2007). These biological active compounds considered largely as chemo protective (Badary et al., 1999 and Badary et al., 2007), gastro protective (El-Abhar et al., 2003; Kanter et al., 2005) and immuno protective (Gilani et al., 2004). The foods rich in fats after absorption through intestine intensify the hepatic detoxification, enhance lipid peroxidation and resulted debris cause cellular modifications. Cholesterol in the blood vessels also constructs fibrosis plaque along the walls. These plaques are atherosclerotic proliferation of the extra cellular matrix formed due to extensive biochemical and molecular changes within the vessels (Glass and Witztum, 2001; Tiwari et al., 2008). Oxidation by free radicals is an imperative incident cause aging and human diseases. 
The antioxidant screening of plants and their phytochemicals through comparing commercial antioxidants could help to find new source of expected innate antioxidants. $N$. sativa and its active components have tremendous potential of nutraceutical and pharmaceutical applications. This needs to be explored through more clinical studies in metabolic syndrome that is the challenge of future to medical professionals. The present study was undertaken to explore probable antioxidant potential of $N$. sativa found in its different parts which is responsible for lowering high blood pressure, serum cholesterol and plasma sugar. The data on the evaluation of $N$. sativa clinically and as antioxidant are scanty. This was the first ever study for validating the therapeutic potential of $N$. sativa in the state of Azad Kashmir, Pakistan.

\section{Methodology and Materials}

\section{Patient Selecting Criterion}

Patients with mild-moderate hypertension were selected from outpatient departments (OPD) of Abbass Institute of Medical Sciences (AIMS) Muzaffarabad and from medical camps organized through AIMS cardiology department. Before starting the study an approval from hospital ethical committee was taken. After explaining all the outcomes of the treatment and taken written consent from all participants (Supplementary Figure 3), pathological history was recorded through questionnaire (Supplementary Figure 1). During selection every aspect of patient interest focussed so that satisfies his convenience in perfection of better compliance. A total of 180 patients were registered for this clinical study which was divided in to two groups, each comprising 90 individuals. All patients were selected from the same geographical area randomly with a male and female ratio of 43:57. Selection of Patients were based on category, MildModerate Hypertension, Systolic Blood Pressure 130-159 mmHg; Diastolic Blood Pressure 80-99 mmHg, Abdominal obesity (Waist circumference): $>102 \mathrm{~cm}$ in males and $>88 \mathrm{~cm}$ in females, Total Cholesterol: $\geq 200 \mathrm{mg} / \mathrm{dL}$, Serum Triglycerides: $>150$ $\mathrm{mg} / \mathrm{dL}, \mathrm{LDL}:>120 \mathrm{mg} / \mathrm{dL}, \mathrm{HDL}:<40 \mathrm{mg} / \mathrm{dl}$ (male) or HDL < $50 \mathrm{mg} / \mathrm{dL}$ (female). Serum Glucose: $\geq 110 \mathrm{mg} / \mathrm{dL}$.

Patient's weight and height were measured for Body Mass Index calculation BMI $\left(\mathrm{Kg} / \mathrm{m}^{2}\right)$. Patient's systolic and diastolic blood pressure was recorded by using mercury Sphygmomanometer (Tycos Japan). Fasting blood samples (Venus) were taken in the hospital pathological laboratory and analysed for all biochemical tests using principal biochemistry analyzer and enzyme assays. Adverse events report proformas (Supplementary Figure 2) to report any adverse event and laboratory proformas (Supplementary Figure 4) to file all base line tests reports were prepared. A copy of each was given to patient for record. Patients were divided randomly including male and female's age ranged from 20-65 years into $N$. sativa and standard statin groups. One group was started with $N$. sativa oil treatment while second on statin standard treatment (atorvastatin $10 \mathrm{mg}$ tablet once a day) and metformin $500 \mathrm{mg}$ tablet one twice a day added to diabetics after taking a baseline data of all biochemical parameters. All the patients were strictly advised to follow the guide lines regarding physical activities, diet and maintained it regularly in routine life style. $N$. sativa seeds virgin oil (NsVO) administered orally twice a day in a dose of $0.5 \mathrm{ml}$ before breakfast and going to bed for sleeping at night. During the study period patients were closely monitored through telephone calls, personal visits and every fortnight calls on hospital visits for blood 
pressure examination. After 45 days patient's blood samples taken in the hospital pathological laboratory and data were analyzed statistically by using paired t-test.

\section{The Antioxidant Assay}

Antioxidant potential of $N$. sativa and edible oils was evaluated by using free radical scavenging DPPH assay (2,2-diphenyl-1-picrylhydrazyl) as described by Amarowicz et al. (2004). The absorbance was recorded at $517 \mathrm{~nm}$ through ultrospec-4000 (PharmaciaLKB) UV-visible spectrophotometer. The radical scavenging activity was expressed as $\mathrm{IC}_{50}$. Ascorbic acid was used as standard. The percentage scavenging activity was calculated by using the following formula:

$$
\text { Percentage Inhibition }=\frac{(\text { A control }-\mathrm{A} \text { extract })}{(\mathrm{A} \text { control })} \times 100
$$

where A control is the absorbance of the control reaction, A extract is the absorbance of the test sample.

\section{Results and Discussion}

The study was undertaken with the aim to compare the antihypertensive and antihyperlipidemic effect of $N$. sativa virgin oil and standard statin treatments with their respective baseline data's in selected area. For this purpose 180 patients was screened out. Out of 180 patients 163 comply while 17 did not due to personal reasons. Statistical analysis showed that $N$. sativa has significant $(\mathrm{P}$-value $=<0.05)$ effect on controlling hypertension (Systolic Bp P=3.079e-07; Diastolic Bp P=2.136e-06) and hyperlipidemia (Total cholesterol $\mathrm{P}=2.2 \mathrm{e}-16$, LDLc $\mathrm{P}=2.2 \mathrm{e}-16$, HDLc $\mathrm{P}=4.739 \mathrm{e}-12$ and TGs $\mathrm{P}=$ 0.05706) as compared to standard group (Systolic Bp P=5.505e-07; Diastolic Bp P = 1.005e-07; Total cholesterol $\mathrm{P}=4.805 \mathrm{e}-13$, LDLc $\mathrm{P}=4.803 \mathrm{e}-10$, HDLc $\mathrm{P}=4.049 \mathrm{e}-06$ and TGs $\mathrm{P}=1.441 \mathrm{e}-07$ ) through its antioxidative activities (Table 4,5 ). The patients receiving $N$. sativa treatment after 45 days the mean systolic $(154.35 \mathrm{mmHg})$ and diastolic $(95.20 \mathrm{mmHg})$ blood pressure at baselines was reduced to $142.80 \mathrm{mmHg}$ and $88.15 \mathrm{mmHg}$ respectively (Table 1; Fig. 1, 3). Among the 83 patients 59 (71\%) showed a significant decreased in blood pressure, $13(16 \%)$ increased and $11(13 \%)$ showed no effect of the treatment (Fig. 2). In comparison to the 2nd group of standard treatment after 45 days the mean systolic $(153.60 \mathrm{mmHg})$ and diastolic $(95.18 \mathrm{mmHg})$ blood pressure at baselines was also reduced to $146.60 \mathrm{mmHg}$ and $90.30 \mathrm{mmHg}$ respectively (Table 1, Fig. 4) but it was less than N. sativa group. Among the 80 patients receiving standard treatment $46(57 \%)$ showed a decreased in blood pressure, $16(20 \%)$ increased and $18(23 \%)$ showed no effect of the treatment (Fig. 3). The percent effect of $N$. sativa $(71 \%)$ at individual levels was also better compared to standard group (57\%). Various traditional and animal studies report the promising hypotensive action of the seeds and extracts of $N$. sativa. Rahman et al. (1990) described the antihypertensive effect of the methanolic seeds extracts of $N$. sativa in the normal and adrenaline induced hypertension. Dehkordi and Kamkhah (2008) suggested that $200 \mathrm{mg} \mathrm{N}$. sativa seeds extract twice daily for 8 weeks significantly lowered down the systolic and diastolic blood pressure. 


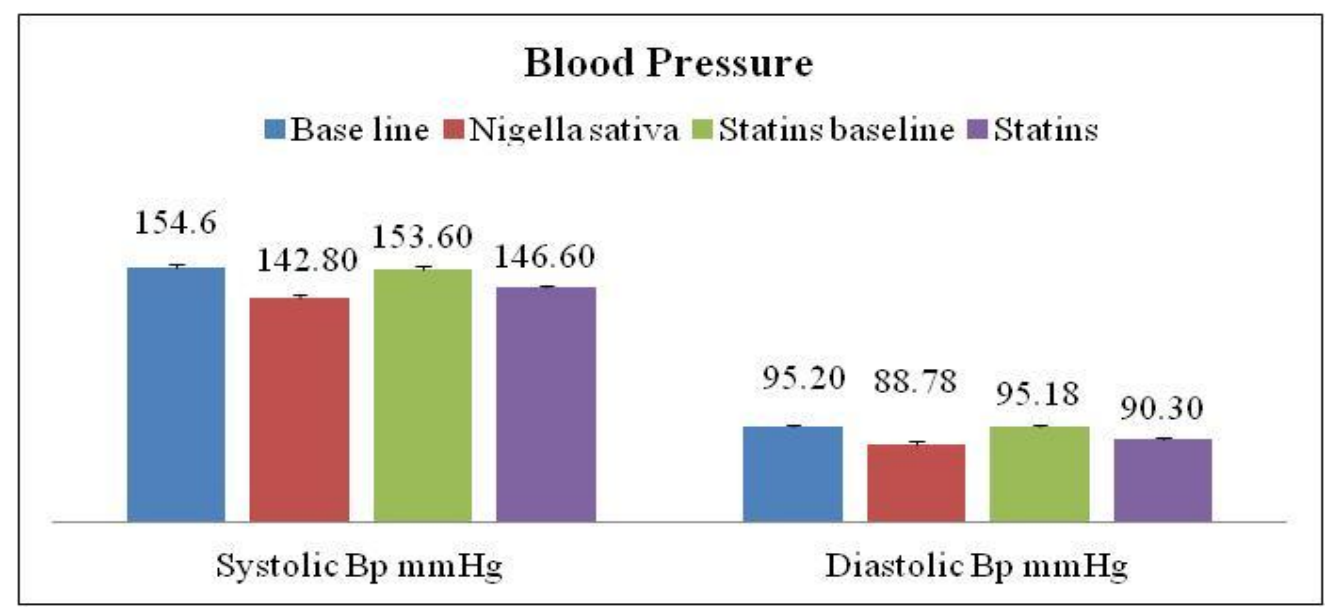

Figure 1. Mean comparison of $N$. sativa patients vs. standard statin at baseline after 45 days treatment

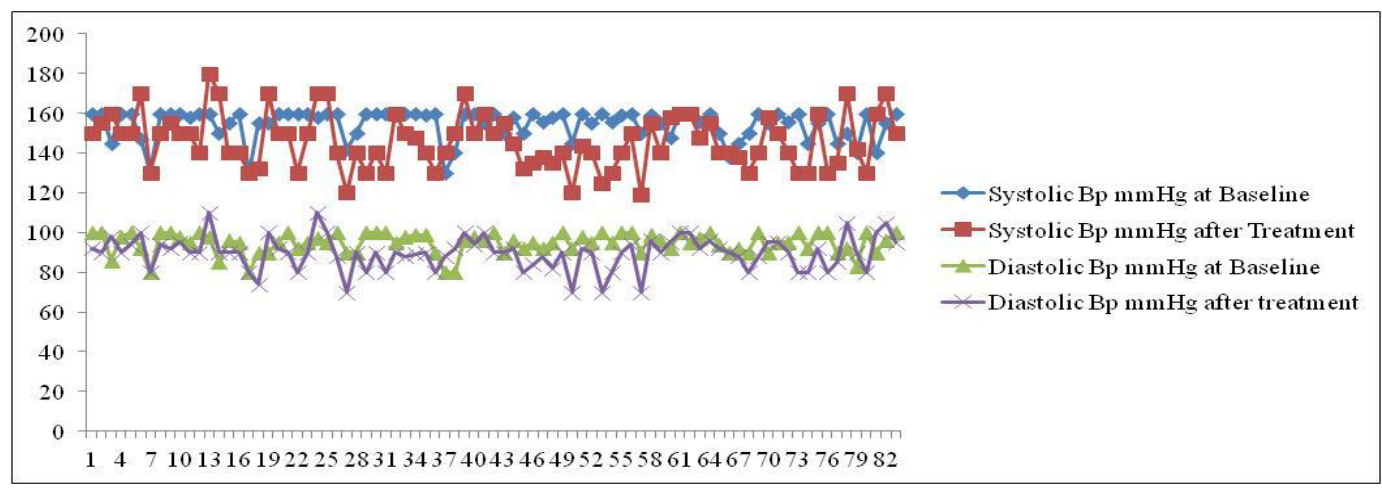

Figure 2. Pattern of systolic and diastolic blood pressure of the individuals after N. sativa treatment at baseline



Figure 3. Pattern of systolic and diastolic blood pressure of the individuals after standard treatment at baseline

The $N$. sativa treatment showed a considerable reduction in the total cholesterol ( 218-205 mg/dl), LDLc ( 135-122 mg/dl) and triglycerides ( 204-194 mg/dl) levels at their baselines as compared to the standard treatment which were $\sim 222-215 \mathrm{mg} / \mathrm{dl}$, $\sim 136-130 \mathrm{mg} / \mathrm{dl}$ and $\sim 190-180 \mathrm{mg} / \mathrm{dl}$ respectively. There was found a significant 
reduction in the mean total cholesterol $(\mathrm{P}=2.2 \mathrm{e}-16)$ and LDLc $(\mathrm{P}=2.2 \mathrm{e}-16)$ in $N$. sativa group as compared to standard group $(\mathrm{P}=4.805 \mathrm{e}-13$ and $\mathrm{P}=4.803 \mathrm{e}-10)$. The effect of seeds extract in animal model (for 12 weeks) has been evaluated by Zaoui et al. (2002) which showed a decrease in the levels of cholesterol, triglycerides and blood glucose. Dekhordi and Kamkhah (2008) depicted that 100 or $200 \mathrm{mg}$ twice daily doses of $N$. sativa significantly reduced the total and LDL cholesterol in a dose dependent manner. Pourghassem-Gargari et al. (2009) and Nader et al. (2010) reported that if black seeds used in diet supplements can effectively decrease the total cholesterol $(43.7 \%)$, LDLc $(42.8 \%)$ and TGs $(34.9 \%)$ after one month of treatment as compared to control. The improvement in HDLc is although low (37.7 3-39.50 mg/dl), however better than in case of standard therapy $(39.18-39.5 \mathrm{mg} / \mathrm{dl})$. The results are in agreement reported by Najmi et al. (2008) and Le et al. (2004).

Reduction in BMI has positive effect on obesity. The treatment with $N$. sativa showed the reduction of BMI $\left(26.22-25.52 \mathrm{~kg} / \mathrm{m}^{2}\right)$ as compared to standard group $\left(27.90-27.38 \mathrm{~kg} / \mathrm{m}^{2}\right)$ however waist in both cases $(\sim 92-91$ and $\sim 98-97 \mathrm{~cm})$ were comparable (Table 1). The reduction in triglyceride levels were also found same in both groups (204-194 mg/dl and 190-180 mg/dl). Similar results were reported by Najmi, et al. (2008) while working with $N$. Sativa. Datau et al. (2010) found a reduction in the body mass index when used $N$. sativa seeds in a dose of $1.5 \mathrm{~g} /$ day for three months in obese individuals. Although their study conferred that the reduction in BMI and waist was not much significant but it had good impact on improving cholesterol. Moreover, In the $N$. sativa group the HDLc was raised $37.73-39.50 \mathrm{mg} / \mathrm{dl}$ while in standard group the value was $39.18-39.50 \mathrm{mg} / \mathrm{dl}$ which showed a significant $(\mathrm{P}=4.739 \mathrm{e}-12)$ augment due to the $N$. sativa treatment. It has also been observed the high impact of the $N$. sativa treatment on the reduction of fasting blood glucose levels $(\sim 150-128 \mathrm{mg} / \mathrm{dl})$ in comparison to the standard treatment ( 147-144 mg/dl) at baseline (Table 1; Fig. 4, 5). The studies of Bamosa et al. (2002) and Najmi, et al. (2008) also supported the findings of the present study on total cholesterol, LDL, HDL, Triglyceride and fasting blood sugar.

Table 1. Mean comparison of $N$. sativa vs. standard treatment at their respective baselines

\begin{tabular}{ccccc}
\hline \multirow{2}{*}{$\begin{array}{c}\text { Biochemical } \\
\text { Parameters }\end{array}$} & \multicolumn{2}{c}{ Control vs. NsVO } & \multicolumn{2}{c}{ Control vs. Statin } \\
\cline { 2 - 5 } & $\begin{array}{c}\text { Before Treatment } \\
\text { Means Value }\end{array}$ & $\begin{array}{c}\text { After Treatment } \\
\text { Means Value }\end{array}$ & $\begin{array}{c}\text { Before Treatment } \\
\text { Means Value }\end{array}$ & $\begin{array}{c}\text { After Treatment } \\
\text { Means Value }\end{array}$ \\
\hline $\begin{array}{c}\text { Systolic Bp } \\
(\mathrm{mmHg})\end{array}$ & 154.35 & 142.80 & 153.60 & 146.60 \\
$\begin{array}{c}\text { Diastolic Bp } \\
(\mathrm{mmHg})\end{array}$ & 95.20 & 88.78 & 95.18 & 90.30 \\
BMI $\left(\mathrm{Kg} / \mathrm{m}^{2}\right)$ & 26.22 & 25.52 & 27.90 & 27.38 \\
Waist $(\mathrm{cm})$ & 92.00 & 91.33 & 98.00 & 97.13 \\
T. Cholesterol & 218.25 & 204.80 & 221.65 & 215.13 \\
$(\mathrm{mg} / \mathrm{dl})$ & 134.63 & 122.10 & 135.75 & 130.10 \\
LDL (mg/dl) & 37.73 & 39.50 & 39.18 & 39.50 \\
HDL (mg/dl) & 203.70 & 193.73 & 189.80 & 180.23 \\
Triglycerides & 149.73 & 128.54 & 146.73 & 143.92 \\
$\quad(\mathrm{mg} / \mathrm{dl})$ & & & & \\
BSF (mg/dl) & & & &
\end{tabular}




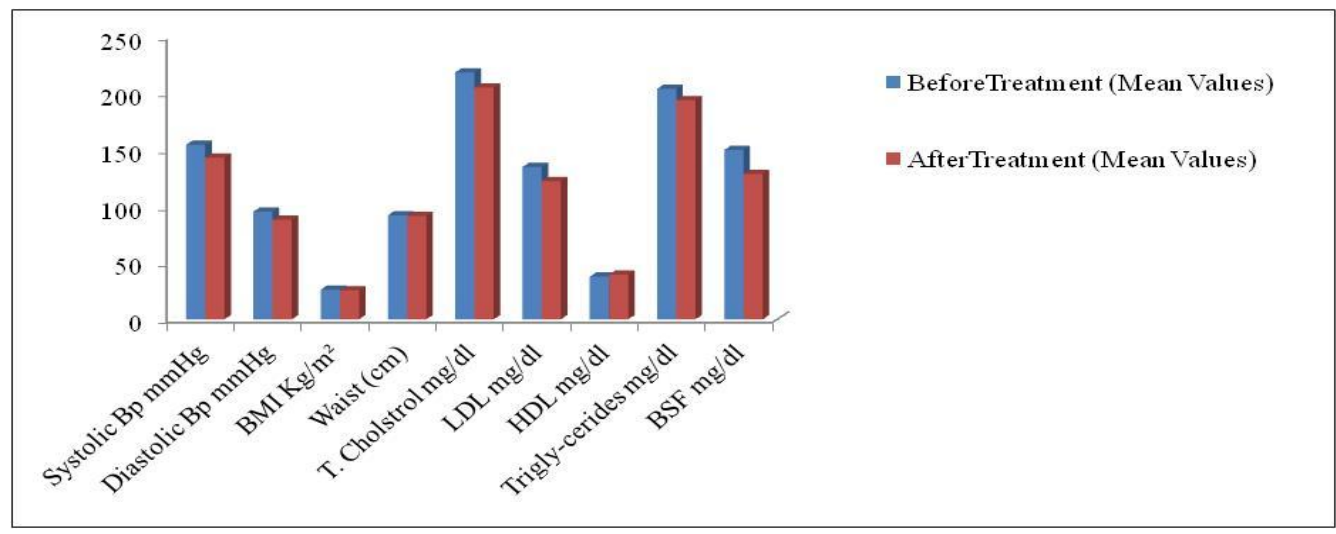

Figure 4. Mean comparison of $N$. sativa patients vs. base line after 45 days treatment

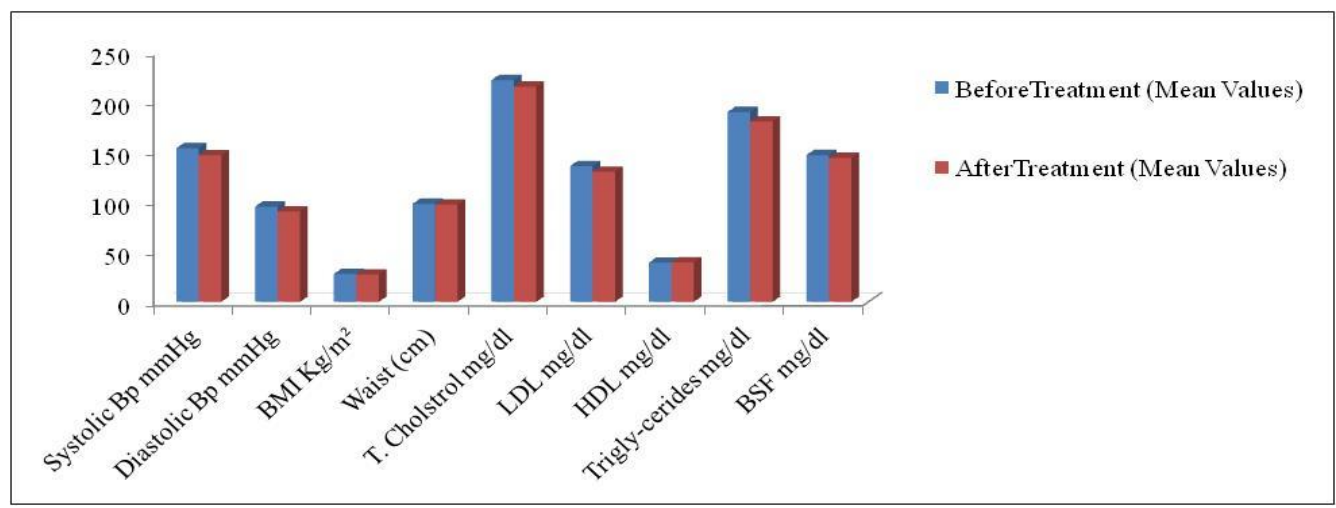

Figure 5. Mean comparison of standard vs. baseline after 45 days treatment

Furthermore, when cholesterol and sugar levels were undertaken resulted lowered down along with blood pressure which also controlled due the fact that an increase in blood pressure found to be linked with increased cholesterol and sugar levels (SiokKoon et al., 2009). The systolic and diastolic blood pressure significantly lowered down with the increased in duration of the $N$. sativa treatment. The systolic blood pressure was decreased to $\sim 134 \mathrm{mmHg}$ after 90 days and $\sim 127 \mathrm{mmHg}$ after 180 days of $N$. sativa treatment at baseline of $\sim 155 \mathrm{mmHg}$ followed by decrease in diastolic blood pressure as $\sim 83 \mathrm{mmHg}$ and $\sim 76 \mathrm{mmHg}$ after 90 and 180 days at baseline of $\sim 94 \mathrm{mmHg}$ respectively (Table 2; Fig. 6). In case of standard treatment the systolic $(\sim 153 \mathrm{mmHg})$ blood pressure was decreased to $\sim 145$ and $138 \mathrm{mmHg}$ after 90 and 180 days while the diastolic ( $\sim 94 \mathrm{mmHg}$ ) was decreased to $\sim 90$ and $\sim 84 \mathrm{mmHg}$ after 90 and 180 days respectively (Table 3; Fig. 7). Similarly patients receiving $N$. sativa showed a remarkable reduction in the mean total cholesterol, LDLc and triglycerides with the increase in HDLc after six month of treatment. The $N$. sativa group significantly reduced the cholesterol (199 and $186 \mathrm{mg} / \mathrm{dl})$, LDLc (113 and $99 \mathrm{mg} / \mathrm{dl})$, triglyceride (168 and $154 \mathrm{mg} / \mathrm{dl})$ and fasting blood sugar (112 and $94 \mathrm{mg} / \mathrm{dl})$ after 90 and 180 days of treatment at baselines of $220 \mathrm{mg} / \mathrm{dl}, 136 \mathrm{mg} / \mathrm{dl}, 191 \mathrm{mg} / \mathrm{dl}$ and $150 \mathrm{mg} / \mathrm{dl}$ respectively. The HDLc was increased to $40.80 \mathrm{mg} / \mathrm{dl}$ and $42.13 \mathrm{mg} / \mathrm{dl}$ at the baseline of $39.05 \mathrm{mg} / \mathrm{dl}$ after 90 and 180 days of $N$. sativa treatment respectively (Table 2; Fig. 6). 
Table 2. Mean comparison of N. sativa group after 45, 90 and 180 days treatment at baseline

\begin{tabular}{ccccc}
\hline Biochemical Parameters & Control & After 45 Days & After 90 Days & After 180 Days \\
\hline Systolic Bp (mmHg) & 155.07 & 142.80 & 134.18 & 127.28 \\
Diastolic Bp (mmHg) & 94.3 & 88.78 & 83.23 & 76.35 \\
BMI $\left(\mathrm{kg} / \mathrm{m}^{2}\right)$ & 26.65 & 25.52 & 25.93 & 25.55 \\
Waist $(\mathrm{cm})$ & 91.75 & 91.33 & 90.15 & 89.13 \\
T. Cholesterol $(\mathrm{mg} / \mathrm{dl})$ & 219.7 & 204.80 & 198.53 & 186.03 \\
LDL $(\mathrm{mg} / \mathrm{dl})$ & 135.9 & 122.10 & 112.70 & 99.20 \\
HDL $(\mathrm{mg} / \mathrm{dl})$ & 39.05 & 39.50 & 40.80 & 42.13 \\
Triglycerides $(\mathrm{mg} / \mathrm{dl})$ & 190.8 & 193.73 & 168.00 & 154.25 \\
BSF $(\mathrm{mg} / \mathrm{dl})$ & 149.73 & 128.54 & 111.73 & 93.73 \\
\hline
\end{tabular}

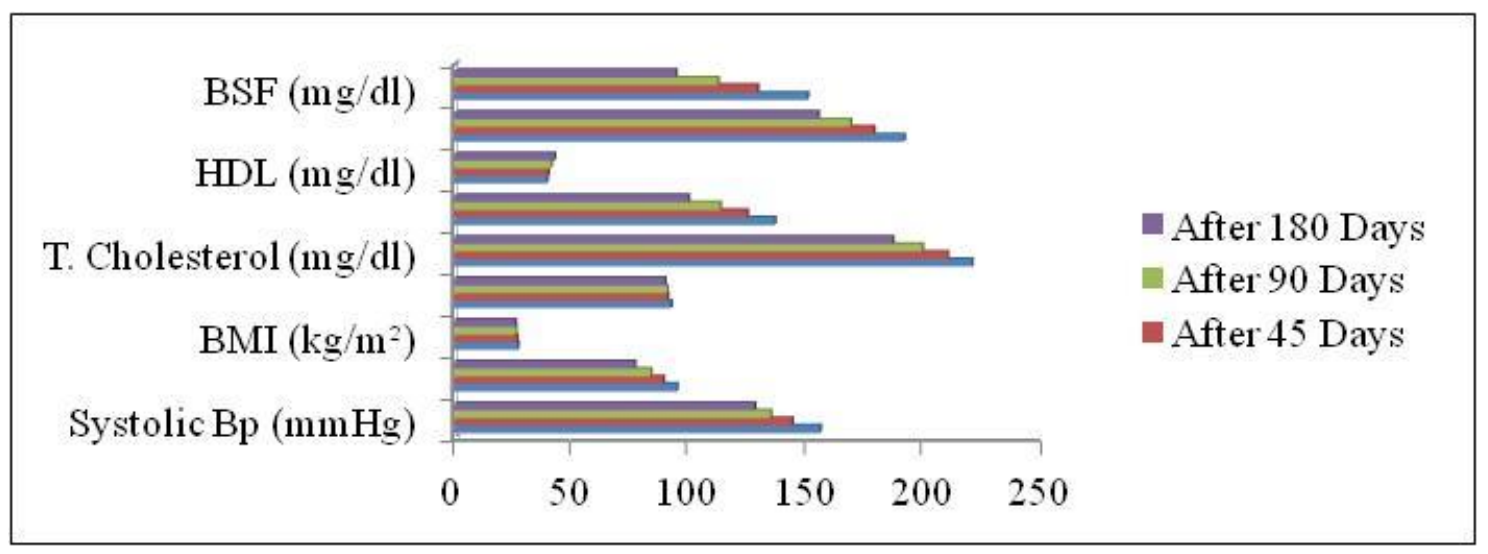

Figure 6. Mean comparison of $N$. sativa group after 45, 90 and 180 days treatment at baseline

Table 3. Mean comparisons of standard group after 45, 90 and 180 days treatment at baseline

\begin{tabular}{ccccc}
\hline Biochemical Parameters & Control & After 45 Days & After 90 Days & After 180 Days \\
\hline Systolic Bp (mmHg) & 153.15 & 146.60 & 145.0 & 137.8 \\
Diastolic Bp (mmHg) & 95.15 & 90.30 & 90.15 & 84.25 \\
BMI $\left(\mathrm{kg} / \mathrm{m}^{2}\right)$ & 27.48 & 27.38 & 26.89 & 26.53 \\
Waist $(\mathrm{cm})$ & 96.65 & 97.13 & 95.8 & 95.1 \\
T. Cholesterol (mg/dl) & 226.95 & 215.13 & 218.4 & 210.07 \\
LDL (mg/dl) & 137.27 & 130.10 & 126.8 & 121.15 \\
HDL (mg/dl) & 38.75 & 39.50 & 39.82 & 40.67 \\
Triglycerides (mg/dl) & 195.07 & 180.23 & 178.22 & 159.57 \\
BSF (mg/dl) & 146.73 & 143.92 & 127.08 & 129.27 \\
\hline
\end{tabular}




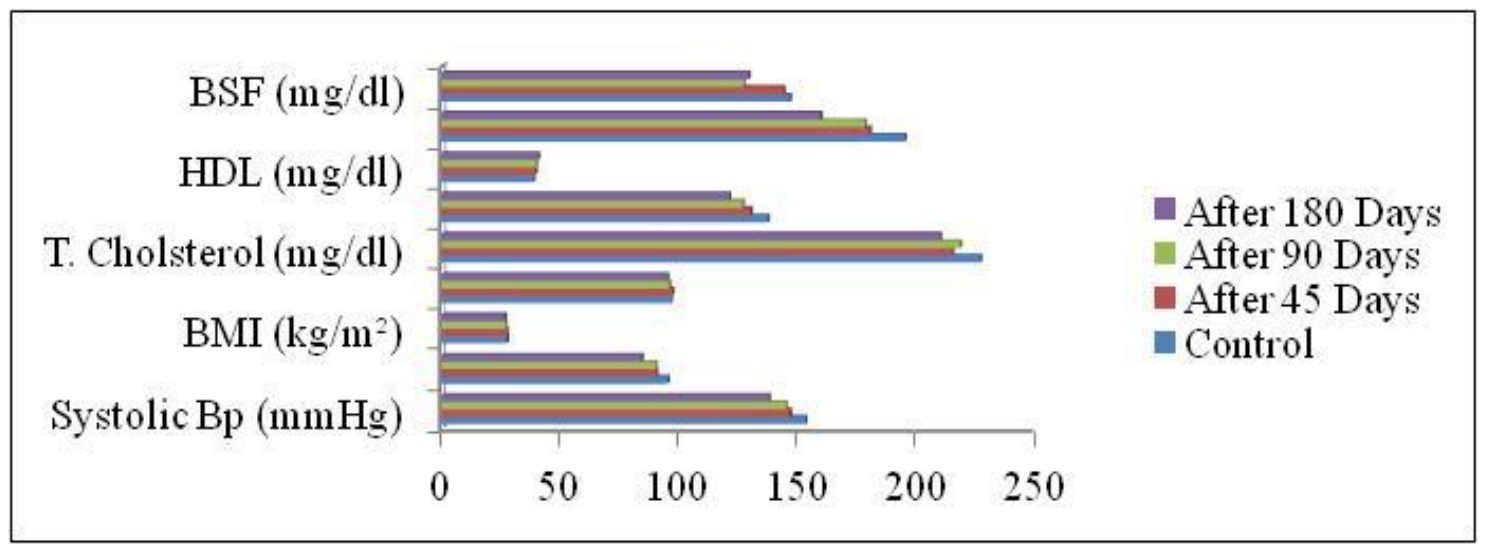

Figure 7. Mean comparisons of standard group after 45, 90 and 180 days treatment at baseline

Table 4. Comparison of variables before and after $N$. sativa treatment using paired t-test

\begin{tabular}{|c|c|c|c|c|c|}
\hline $\begin{array}{c}\text { Variables of } N \text {. sativa } \\
\text { Group }\end{array}$ & $\begin{array}{c}\text { T- } \\
\text { values }\end{array}$ & DF & P-values & $\begin{array}{c}\text { 95\% Confidence } \\
\text { Interval }\end{array}$ & Remarks \\
\hline Systolic Bp (mmHg) & 5.57 & 82 & $3.079 \mathrm{e}-07$ & $\begin{array}{c}5.656962 \\
11.933400\end{array}$ & Significant \\
\hline Diastolic Bp (mmHg) & 5.10 & 82 & $2.136 \mathrm{e}-06$ & 3.123754 & Significant \\
\hline $\mathrm{BMI}\left(\mathrm{Kg} / \mathrm{m}^{2}\right)$ & 9.57 & 82 & $5.284 \mathrm{e}-15$ & $\begin{array}{l}0.4335806 \\
0.6611182\end{array}$ & Significant \\
\hline Waist (cm) & 5.56 & 82 & 3.215 e- 07 & $\begin{array}{l}0.6967115 \\
1.4719632\end{array}$ & Significant \\
\hline T.Cholesterol (mg/dl) & 11.12 & 82 & $2.200 \mathrm{e}-16$ & $\begin{array}{c}9.130463 \\
13.110501\end{array}$ & Significant \\
\hline $\operatorname{LDL}(\mathrm{mg} / \mathrm{dl})$ & 11.015 & 82 & $2.200 \mathrm{e}-16$ & $\begin{array}{c}9.072539 \\
13.072039\end{array}$ & Significant \\
\hline $\operatorname{HDL}(\mathrm{mg} / \mathrm{dl})$ & 8.085 & 82 & $4.739 \mathrm{e}-12$ & $\begin{array}{l}0.8538746 \\
1.4111856\end{array}$ & Significant \\
\hline $\mathrm{TG}(\mathrm{mg} / \mathrm{dl})$ & 1.93 & 82 & 0.05706 & $\begin{array}{l}-0.1847185 \\
12.2088148\end{array}$ & Insignificant \\
\hline
\end{tabular}

Table 5. Comparison of variables after and before standard treatment using paired t-test

\begin{tabular}{|c|c|c|c|c|c|}
\hline $\begin{array}{c}\begin{array}{c}\text { Variables of Standard } \\
\text { Group }\end{array} \\
\end{array}$ & T-values & DF & P-values & $\begin{array}{c}\text { 95\% Confidence } \\
\text { Interval }\end{array}$ & Remarks \\
\hline Systolic Bp (mmHg) & 5.4524 & 79 & $5.505 \mathrm{e}-07$ & $\begin{array}{l}3.97632 \\
8.54868\end{array}$ & Significant \\
\hline Diastolic Bp (mmHg) & 5.8629 & 79 & $1.005 \mathrm{e}-07$ & $\begin{array}{l}2.617235 \\
5.307765\end{array}$ & Significant \\
\hline BMI $\left(\mathrm{Kg} / \mathrm{m}^{2}\right)$ & 0.9611 & 79 & 0.3394 & $\begin{array}{l}-0.2577192 \\
0.7389692\end{array}$ & Insignificant \\
\hline Waist $(\mathrm{cm})$ & 5.0999 & 79 & $2.279 \mathrm{e}-06$ & $\begin{array}{l}0.4725213 \\
1.0774787\end{array}$ & Significant \\
\hline T. Cholesterol (mg/dl) & 8.6449 & 79 & 4.805 e- -13 & $\begin{array}{l}4.464578 \\
7.135422\end{array}$ & Significant \\
\hline $\operatorname{LDL}(\mathrm{mg} / \mathrm{dl})$ & 7.1002 & 79 & $4.803 \mathrm{e}-10$ & $\begin{array}{l}4.039113 \\
7.185887\end{array}$ & Significant \\
\hline $\operatorname{HDL}(\mathrm{mg} / \mathrm{dl})$ & 4.9542 & 79 & $4.049 \mathrm{e}-06$ & $\begin{array}{l}0.2392906 \\
0.5607094\end{array}$ & Significant \\
\hline $\mathrm{TG}(\mathrm{mg} / \mathrm{dl})$ & 5.7769 & 79 & $1.441 \mathrm{e}-07$ & $\begin{array}{c}5.866225 \\
12.033775\end{array}$ & Significant \\
\hline
\end{tabular}


The systolic and diastolic Bp significantly ( $\mathrm{P}$-value $=<0.05)$ decreased when treatment of $N$. sativa was continued for another 45 days. The systolic and diastolic blood pressure was raised from $\sim 143-148 \mathrm{mmHg}$ and $\sim 88-94 \mathrm{mmHg}$ respectively when that group of patients was treated with placebo however, the total cholesterol was increased from $\sim 200-209 \mathrm{mg} / \mathrm{dl}$ and LDLc $\sim 102-125 \mathrm{mg} / \mathrm{dl}$ while no significant change was recorded in the levels of HDLc and triglycerides. Moreover a little change conferred in BMI (25.52-25.33 kg/m²) and waist circumference $(91.32-90.12 \mathrm{~cm})$ while blood sugar was raised from $128-146 \mathrm{mg} / \mathrm{dl}$ (Table 6 ).

Table 6. Comparison of variables before and after placebo treatment using paired t-test

\begin{tabular}{|c|c|c|c|c|c|}
\hline $\begin{array}{c}\text { Variables of } \\
\text { Placebo Group }\end{array}$ & $\begin{array}{c}\text { T- } \\
\text { values }\end{array}$ & $\begin{array}{l}\text { Degree of } \\
\text { freedom }\end{array}$ & P-values & $\begin{array}{c}\text { 95\% Confidence } \\
\text { Interval }\end{array}$ & Remarks \\
\hline $\begin{array}{l}\text { Systolic Bp } \\
(\mathrm{mmHg})\end{array}$ & 2.6223 & 39 & 0.01239 & $\begin{array}{l}1.126098 \\
8.723902\end{array}$ & Significant \\
\hline $\begin{array}{l}\text { Diastolic Bp } \\
\quad(\mathrm{mmHg})\end{array}$ & 4.5873 & 39 & $4.562 \mathrm{e}-05$ & $\begin{array}{l}3.032939 \\
7.817061\end{array}$ & Significant \\
\hline BMI $\left(\mathrm{kg} / \mathrm{m}^{2}\right)$ & 3.2084 & 39 & 0.002669 & 0.045178910 .19932109 & Significant \\
\hline Waist $(\mathrm{cm})$ & -1 & 39 & 0.3235 & $\begin{array}{c}-0.15113455 \\
0.05113455\end{array}$ & Insignificant \\
\hline $\begin{array}{l}\text { T.Cholesterol } \\
\text { (mg/dl) }\end{array}$ & 5.8299 & 39 & $8.924 \times 10^{\wedge}-07$ & $\begin{array}{l}4.163177 \\
8.586823\end{array}$ & Significant \\
\hline $\mathrm{LDL}(\mathrm{mg} / \mathrm{dl})$ & 5.4011 & 39 & $3.509 \mathrm{e}-06$ & 8.89778319 .552217 & Significant \\
\hline HDL (mg/dl) & 2.6234 & 39 & 0.01236 & $\begin{array}{c}-0.26565178- \\
0.03434822\end{array}$ & Significant \\
\hline TG (mg/dl) & 1.1905 & 39 & 0.241 & -1.7998436 .949843 & Insignificant \\
\hline $\mathrm{BSF}(\mathrm{mg} / \mathrm{dl})$ & 6.9145 & 25 & $3.011 \mathrm{e}-07$ & $\begin{array}{l}12.42255 \\
22.96206\end{array}$ & significant \\
\hline
\end{tabular}

The antioxidant activity of the extracts of all lines of $N$. sativa was assessed by using $\mathrm{DPPH}$ assay and $\mathrm{IC}_{50}$ value recorded was tabulated in Table 7. Among seven lines tested, the N1 sample was found to be potent (Table 7; Fig. 8). When compared different solvents extracts, the ethyl acetate was found to be a potent solvent for the extraction of potential compound with $\mathrm{IC}_{50}$ values for $\mathrm{N} 1(0.0022), \mathrm{N} 2(0.0033), \mathrm{N} 3$ (0.0030) and N7 (0.4476) while methanol, chloroform and acetone extracts showed least activity (Table 7; Fig. 8). Due to the factual antioxidant potential of seeds of $N$. sativa, a detail screening of all parts was carried out. Here also the N7 line was found to be potent. The $\mathrm{IC}_{50}$ value recorded for ripen seeds was 0.000415 followed by unripe (green seeds) i.e. 3.510731 as compared to the standard used (Table 8; Fig. 9a and 3c). Other parts were found to be rubbished (Table 8; Fig. 9b). Vinha et al. (2005) reported that variation in antioxidant potential among all parts of same genotype was due to variation in secondary metabolites in different parts or may be due to extraction procedures, which is adopted for the extraction of active constituents. Commercially available edible oils were also screened with the purpose to compare their potential with selected genotype. It was found that $N$. sativa had great antioxidant potential as compared to the edible oils tested (Table 9; Fig. 9d). According to Skerget et al. (2005) sometime sampling of the same plant from the same ecological zone may deviate to the potential behavior because of mishandling of sampling procedures that could immediately oxidized the active metabolites and the antioxidant ability of the plants. 
Yoruk et al. (2010) also reported significant antioxidant potential of $N$. sativa preventing oxidative stress by scavenging reactive oxygen species. The current results were in harmony with the previous studies.

In the present findings of clinical studies the use of $N$. sativa virgin oil (N7) revealed a significant reduction in the blood pressure and other biochemical parameters. The evidence from literature also supports the findings that the antioxidants protect the body against the development of atherosclerosis and provide putative hypotensive effects (Rohdewald, 2002; Paulis and Simko, 2007). Antioxidants contained melatonin (Flavonoids) can effectively be used in reducing blood pressure, lipid profile, body weight and plasma glucose (Hussein et al., 2007). Antioxidants have strong impact of reducing the blood pressure which is also supported by a recent study (Rezzani et al., 2010) that described the protective role of antioxidants against the initiation of atherosclerosis in hypertensive animal model. Houghton et al. (1995) reported that the biologically active constituents of $N$. sativa had potent quenching capabilities for free radicals. On the basis of present findings it is conferred that the poor antioxidant effects in treating various pathological conditions are more or less due to improper dosage, methods of extraction, selection of the seeds cultivar and the selection of the seeds lots. So it is suggested that only an intellectual approach could succeed in achieving the desired results while implementing any treatment of plant material consisting these oxidants. Moreover the oxidative stress promptly impregnate its harmful effects on the arterial vasculature that require long time to correct in a smoothly manner. Allopathic drugs although provide to some instant relieve to the inflammation of the endothelial linings of the vasculature but could not be the sole solution to the whole imploratory process of atherosclerosis.

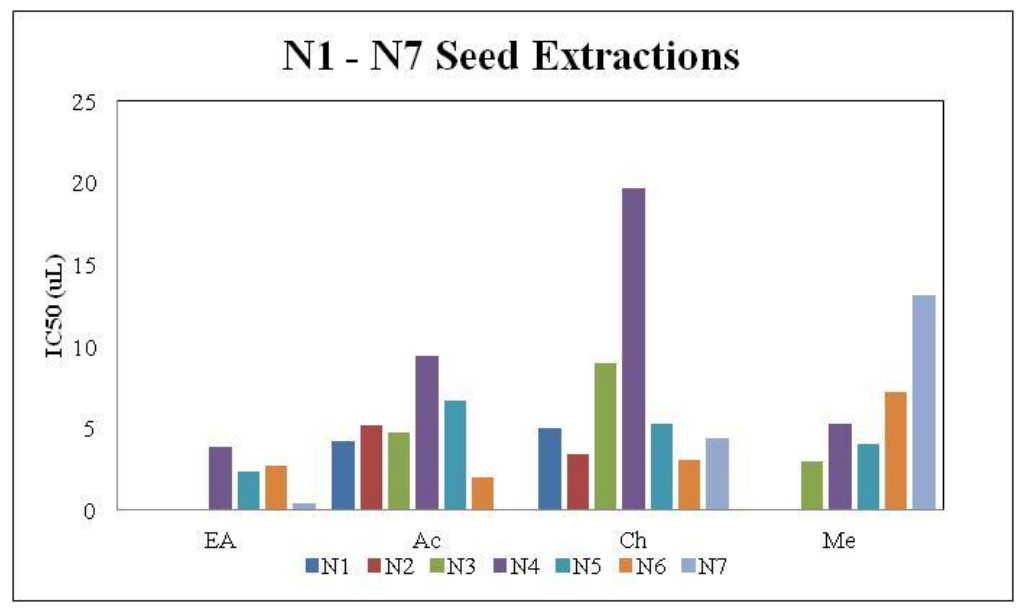

Figure 8. Comparison of antioxidant activities of N. sativa seeds in four solvent extracts of seven lines in different concentrations and IC50 values

\section{Conclusion}

On the basis of the current investigations it is concluded that $N$. sativa seeds and oil should be considered routinely in the management of diabetic and hypercholesterolemic disorders as remedy was found to be potent hypotensive, antihyperlipidemic and hypoglycaemic with strong antioxidative activities without any adverse effect. Nigella sativa proved to be the best alternatives remedial source to cure these fatal ailments with 
remarkable benefits of many other concomitant cures. However more investigations are needed to isolate bioactive compounds that are responsible of managing high blood pressure and other biochemical disorders.

Figure 1 (A): Nigella sativa oil VS standards

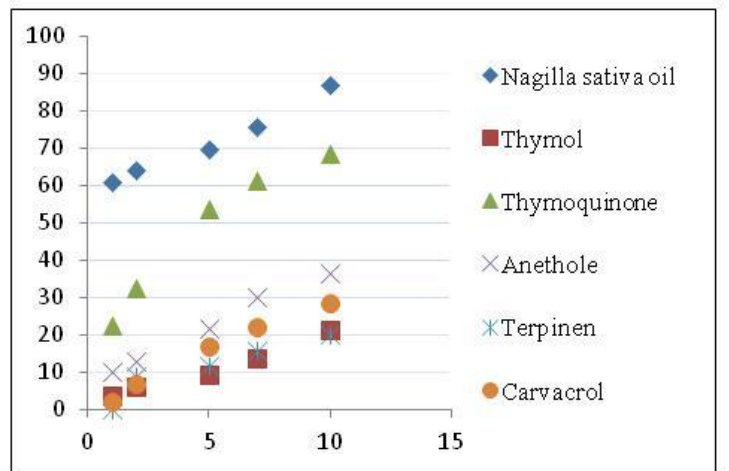

(C): Antioxidant potential of Nigella sativa all parts and Standard

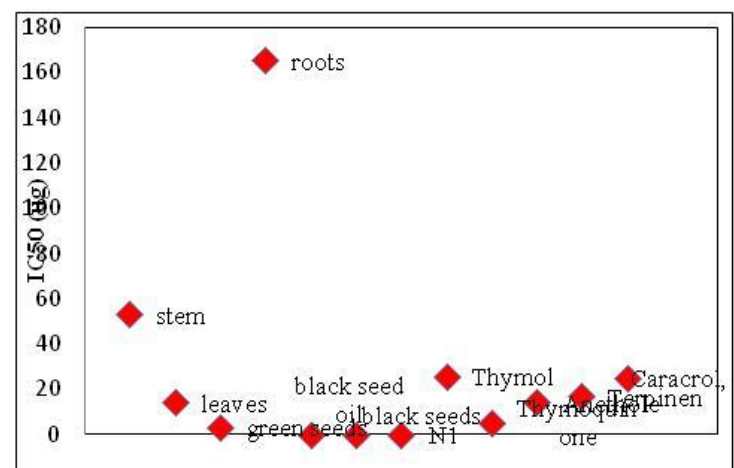

(B): Nigella sativa all parts

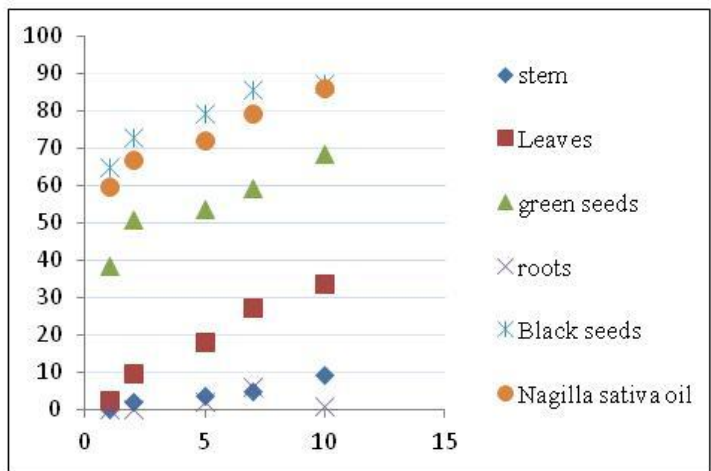

(D): Antioxidant potential of Nigella sativa all lines and other edible oils

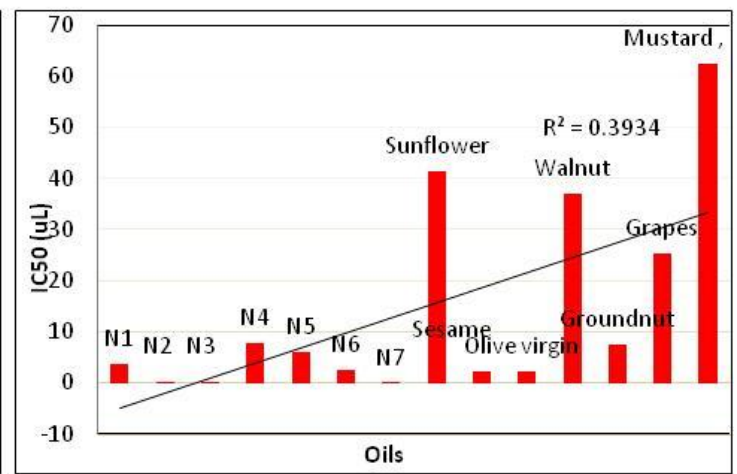

Figure 9. Antioxidant activities of $N$. sativa seeds oil VS standards (A), all parts (B), all parts $V S$ standards $(C)$ and all seven lines VS other edible oils

Table 7. Comparison of antioxidant activities of $N$. sativa seeds in four solvent extracts of seven lines in different concentrations and $I C_{50}$ values

\begin{tabular}{cccc}
\hline Samples & Solvent & $\mathbf{1} \boldsymbol{\mu} \mathbf{l}_{\%}$ & $\mathbf{I C}_{\mathbf{5 0}}$ \\
\hline N1 & Ethyl acetate & 51.12 & 0.002266 \\
N1 & Acetone & 25.89 & 4.199698 \\
N1 & Chloroform & 27.45 & 5.0361 \\
N1 & Methanol & 45.48 & 0.00217 \\
N2 & Ethyl acetate & 68.99 & 0.00335 \\
N2 & Acetone & 16.22 & 5.204309 \\
N2 & Chloroform & 36.28 & 3.474909 \\
N2 & Methanol & 59.79 & 0.00255 \\
N3 & Ethyl acetate & 49.89 & 0.002035 \\
N3 & Acetone & 29.94 & 4.721764 \\
N3 & Chloroform & 30.69 & 8.978789 \\
N3 & Methanol & 28.87 & 2.963774 \\
N4 & Ethyl acetate & 51.04 & 3.859536 \\
N4 & Acetone & 09.33 & 9.405586 \\
N4 & Chloroform & 16.32 & 19.64961
\end{tabular}




\begin{tabular}{lccl} 
N4 & Methanol & 16.00 & 5.326029 \\
N5 & Ethyl acetate & 36.17 & 2.412749 \\
N5 & Acetone & 21.43 & 6.666936 \\
N5 & Chloroform & 25.99 & 5.312122 \\
N5 & Methanol & 38.92 & 4.090206 \\
N6 & Ethyl acetate & 53.18 & 2.721577 \\
N6 & Acetone & 37.11 & 2.038345 \\
N6 & Chloroform & 29.98 & 3.098866 \\
N6 & Methanol & 47.00 & 7.267184 \\
N7 & Ethyl acetate & 55.89 & 0.447679 \\
N7 & Acetone & 28.65 & 0.003108 \\
N7 & Chloroform & 21.08 & 4.366061 \\
N7 & Methanol & 34.00 & 13.11741 \\
\hline
\end{tabular}

Table 8. Antioxidant potential of all parts of $N$. sativa versus its five standards used

\begin{tabular}{cccc}
\hline S. No. & Plant parts and Standards used & $\mathbf{1} \boldsymbol{\mu l}$ & $\mathbf{I C}_{\mathbf{5 0}}$ \\
\hline 1 & Stem & 00.08 & 53.24247 \\
2 & Leaves & 02.55 & 14.32170 \\
3 & Green Seeds & 38.56 & 3.510731 \\
4 & Roots & 00.01 & 165.3653 \\
5 & Ripened Seeds & 65.08 & 0.000415 \\
6 & Milled Oil & 59.89 & 0.000359 \\
7 & Thymol & 03.66 & 25.75068 \\
8 & Thymoquinone & 22.56 & 5.423880 \\
9 & t-Anethole & 10.29 & 14.15704 \\
10 & Terpinen & 00.03 & 16.88444 \\
11 & Carvacrol & 02.11 & 24.97511 \\
\hline
\end{tabular}

Table 9. Antioxidant activities of other edible oils available in the market and IC50 values

\begin{tabular}{cccc}
\hline Samples & Solvent & $\mathbf{1} \boldsymbol{\mu l}_{\boldsymbol{\%}}$ & $\mathbf{I C}_{\mathbf{5 0}}$ \\
\hline Oil & Sunflower & 00.08 & 41.3329 \\
Oil & Sesame & 46.99 & 2.273876 \\
Oil & Olive virgin & 48.33 & 2.160575 \\
Oil & Walnut & 04.44 & 36.98957 \\
Oil & Groundnut & 00.01 & 7.588462 \\
Oil & Grapes & 00.91 & 25.44962 \\
Oil & Mustard & 23.76 & 62.50398 \\
\hline
\end{tabular}

The beneficial effects of $N$. sativa in diabetic's subjects with fasting sugar, LDL, triglycerides, total cholesterol, BMI and high blood pressure were investigated and found highly significant $(\mathrm{P}=<0.05)$ although the $N$. sativa was comparable to standards in short term but in longer therapy $N$. sativa revealed excellent role in controlling biochemical disorders. Maintaining serum glucose, serum cholesterol and high blood pressure at optimum reduces atherosclerosis and subsequently the risk of coronary heart diseases, a major threat to diabetic and hyperlipidemic patients. The potent antioxidative activities of $N$. sativa played a central role in functional optimization of biochemical parameters. 


\section{REFERENCES}

[1] Aqel, M. (1992): The relaxing effect of the volatile oil of Nigella sativa seeds on vascular smooth muscle. - Pure and Applied Sciences Series B 19: 91-100.

[2] Amarowicz, R., Pegg, R. B., Rahimi-Moghaddam, P., Barl, B., Weil, J. A. (2004): Freeradical scavenging capacity and antioxidant activity of selected plant species from the Canadian prairies. - Food Chemistry 84(4): 551-562.

[3] Badary, O. A., Al-Shabanah, O. A., Nagi, M. N., Al-Rikabi, A. C., Elmazar, M. M. (1999): Inhibition of benzopyrene-induced for stomach carcinogenesis in mice by thymoquinone. - European Journal of Cancer Prevention 8(5): 435-440.

[4] Badary, O. A., Ellah, M. F., El-Mahdy, M. A., Salama, S. A., Hamada, F. M. (2007): Anticlastogenic activity of thymoquinone against benzopyrene in mice. - Food and Chemical Toxicology 45(1): 88-92.

[5] Bamosa, A. O., Ali, B. A., Sowayan, S. A. (1997): Effect of oral ingestion of Nigella sativa seeds on some blood parameters. - Saudi Pharmacological Journal 5(2-3): 126129.

[6] Bamosa, A. O., Ali, B. A., Al-Hawsawi, Z. A. (2002): The effect of thymoquinone on blood lipids in rats. - Indian Journal of Physiological Pharmacology 46(2): 195-201.

[7] Bamosa, A., Kaatabi, H., Lebda, F. M., Elq, A. M. A., Sultan, A. (2010): Effect of Nigella sativa Seeds on the Glycemic Control of Patients with Type 2 Diabetes Mellitus. - Indian Journal of Physiological Pharmacology 54 (4): 344-354.

[8] Burits, M., Bucar, F. (2000): Antioxidant activity of Nigella sativa essential oil. Phytotherapy Research 14(5): 323-328.

[9] Datau, E. A., Wardhana, Surachmanto, E. E., Pandelaki, K., Langi, J. A. (2010): Efficacy of Nigella sativa on serum free testosterone and metabolic disturbances in central obese male. - Acta Medicina Indonesia 42(3):130-134.

[10] Dehkordi, F. R., Kamkhah, A. F. (2008): Antihypertensive effect of Nigella sativa seed extract in patients with mild hypertension. - Fundamental \& Clinical Pharmacology 22(4): 447-452.

[11] El-Abhar, H. S., Abdallah, D. M., Saleh, S. (2003): Gastroprotective activity of Nigella sativa oil and its constituent, thymoquinone, against gastric mucosal injury induced by ischaemia/reperfusion in rats. - Journal of Ethnopharmacology 84(2-3): 251-258.

[12] El-Dakhakhany, M., Mady, N. L., Halim, N. L. (2000): Nigella sativa Oil Protects against Induced Hepatotoxicity and Improves Serum Lipid Profile in Rats. Arzneimittelforschung 50(9): 832-836.

[13] El-Saleh, S. C., Al-Sagair, O. A., Al-Khalaf, M. I. (2004): Thymoquinone and Nigella sativa Oil Protection Against Methionine-induced Hyperhomocysteinemia in Rats. International Journal of Cardiology 93(1): 19-23.

[14] Fuentes, R., Ilmaniemi, N., Laurikainen, E., Tuomilehto, J., Nissinen, A. (2000): Hypertension in developing economies: a review of population-based studies carried out from 1980 to 998. - Journal of Hypertension 18(5): 521-529.

[15] Gilani, A.H., Jabeen, Q., Khan, M. A. U. (2004). A review of medicinal uses and pharmacological activities of Nigella sativa. - Pakistan Journal of Biological Sciences 7(4): 441-51.

[16] Glass, C. K., Witztum, J. L. (2001): Atherosclerosis: The Road ahead. - Cell 104(4): 503-516.

[17] Houghton, P. J., Zarka, R., de las Heras, B., Hoult, J. R. (1995): Fixed oil of Nigella sativa and derived thymoquinone inhibit eicosanoid generation in leukocytes and membrane lipid peroxidation. - Planta Medica 61(1): 33-36.

[18] Hussein, M. R., Ahmed, O. G. Hassa, A. F., Ahmed, M. A. (2007): Intake of melatonin is associated with amelioration of physiological changes, both metabolic and morphological pathologies associated with obesity: an animal model. - International Journal of Experimental Patholology 88(1): 19-29. 
[19] Hobbs, F. D. R. (2004): Primary Prevention of Cardiovascular Disease. Managing Hypertension and Hyperlipidaemia. - Heart 90: 22-25.

[20] Kanter, M., Coskun, O., Korkmaz, A., Oter, S. (2005). Effects of Nigella sativa on oxidative stress and beta-cell damage in streptozotocin-induced diabetic rats. Discoveries in Molecular, Cellular and Evolutional Biology Part A: The Anatomical Record 279(1): 685-691.

[21] Kayima, J., Wanyenze, R. K., Katamba, A., Leontsini, E., Nuwaha, F. (2013): Hypertension awareness, treatment and control in Africa: a systematic review. - BMC Cardiovascular Disorders 13: 54.

[22] Kearney, P. M., Whelton, M., Reynolds, K., Muntner, P., Whelton, P. K., He, J. (2005): Global burden of hypertension: analysis of worldwide data. - Lancet 365(9455): 217-223.

[23] Khalife, K. H., Lupidi, G. (2007). Nonenzymatic reduction of thymoquinone in physiological conditions. - Free Radical Research 41(2): 153-161.

[24] Klag, M. J., Whelton, P. K., Randall, B. L., Neaton, J. D., Brancati, F. L., Ford, C. E., Shulman, N. B., Stamler, J. (1996): Blood pressure and end-stage renal disease in men. The New England Journal of Medicine 334(1): 13-18.

[25] Le, P. M., Benhaddou-Andaloussi, A., Elimadi, A., Settaf, A., Cherrah, Y., Haddad, P. S. (2004): The petroleum ether extract of Nigella sativa exerts lipid-lowering and insulinsensitizing actions in the rat. - Journal of Ethnopharmcology 94(2-3): 251-259.

[26] Ma, W. J., Tang, J. L., Zhang, Y. H., Xu, Y. J., Lin, J. Y. (2012): Hypertension prevalence, awareness, treatment, control, and associated factors in adults in southern China. - American Journal Hypertension 25(5): 590-596.

[27] Meral, I., Yener, Z., Kahraman, T., Mert, N. (2001): Effect of Nigella sativa on glucose concentration, lipid peroxidation, anti-oxidant defence system and liver damage in experimentally-induced diabetic rabbits. - Journal of Veterinary Meditine A: Physiology, Pathology, Clinical Medicine. 48(10): 593-599.

[28] Najmi, A., Nasiruddin, M., Khan, R. A. (2008): Effect of Nigella sativa oil on various clinical and biochemical parameters of insulin resistance syndrome. - International Journal of Diabetes in Developing Countries 28(1): 11-14.

[29] Nader, M. A., El-Agamy, D. S., Suddek, G. M. (2010): Protective effects of propolis and thymoquinone on development of atherosclerosis in cholesterol-fed rabbits. - Archives of Pharmacal Research 33(4): 637-643.

[30] Paulis, L., Simko, F. (2007): Blood pressure modulation and cardiovascular protection by melatonin: potential mechanisms behind. - Physiological Research 56(6): 671-684.

[31] Pourghassem-Gargari, B., Ebrahimzadeh-Attary, V., Rafraf, M., Gorbani, A. (2009). Effect of dietary supplementation with Nigella sativa L. on serum lipid profile, lipid peroxidation and antioxidant defense system in hyperlipidemic rabbits. - Journal of Medical Plants Research 3(10): 815-821.

[32] Rahman, M. S., Rafiquzzamn, M., Choudhury, S. A. R. (1990): Antihypertensive activity of Nigella sativa. - Traditional Medicine: 94-96.

[33] Ramadan, M. F. (2007): Nutritional Value, Functional Properties and Nutraceutical Applications of Black cumin (Nigella sativa L.): An overview. - International Journal of Food Science Technology 42(10): 1208-1218.

[34] Rchid, H., Chevassus, H., Nmila, R., Guiral, C., Petit, P., Chokaïri, M., Sauvaire, Y. (2004): Nigella sativa ex-tracts enhance glucose-induced insulin release from rat-isolated Langerhans islets. - Fundamental and Clinical Pharmacology 18(5): 525-529.

[35] Reinhart, K. M., Coleman, C. I., Teevan, C., Vachhani, P., White, C. M. (2008): Effects of garlic on blood pressure in patients with and without systolic hypertension: a metaanalysis. - Annals of Pharmacotherapy 42(12): 1766-1771.

[36] Rezzani, R., Porteri, E., De Ciuceis, C., Bonomini, F., Rodella, L. F., Paiardi, S., Boari, G. E. M., Platto, C., Pilu, A., Avanzi, D., Rizzoni, D., Agabiti, R. E. (2010): Effects of melatonin and Pycnogenol on small artery structure and function in spontaneously hypertensive rats. - Hypertension 55(6): 1373-1380. 
[37] Rohdewald, P. (2002): A review of the French maritime pine bark extract (Pycnogenol), a Herbal medication with a diverse clinical pharmacology. - International Journal of Clinical Pharmacological Therapy 40(4): 158-168.

[38] Rodgers, A., Ezzati, M., Vander Hoorn, S., Lopez, A. D., Lin, R.B., Murray, C. J. (Comparative Risk Assessment Collaborating Group) (2004): Distribution of major health risks: findings from the Global Burden of Disease study. - PLOS Medicine 1(1): e27.

[39] Rostand, S. G., Brunzell, J. D., Cannon, R. O., Victor, R. G. (1991): Cardiovascular complications in renal failure. - Journal of American Society of Nephrology 2(6): 10531062 .

[40] Schumann, L., Emerson, B. (1998): Diagnostic evaluation for hypertension. - Journal of American Academy of Nurse Practitioners 10(6): 269-280.

[41] Siok-Koon, Y., Lay-Gaik, O., Ting-Jin, L., Min-Tze, L. (2002): Antihypertensive Properties of Plant-Based Prebiotics. - International Journal of Molecular Sciences 10(8): 3517-3530.

[42] Skerget, M., Kotnik, P., Hadolin, M., Hras, A. R., Simonic, M., Knez, Z. (2005): Phenols, proanthocyanidins, flavones and flavonols in some plant materials and their antioxidant activities. - Food Chemistry 89(2): 191-198.

[43] Tasawar, Z., Siraj, Z., Ahmad, N., Lashari, M. H. (2011): The Effects of Nigella sativa (Kalonji) on Lipid Profile in Patients with Stable Coronary Artery Disease in Multan, Pakistan. - Pakistan Journal of Nutrition 10(2): 162-167.

[44] Tiwari, R. L., Singh, V., Barthwal, M. K. (2008): Macrophages: An Elusive yet Emerging Therapeutic Target of Atherosclerosis. - Medicinal Research Reviews 28(4): 483-544.

[45] Vega, G. L. (2001): Obesity, the metabolic syndrome, and cardiovascular disease. Americal Heart Journal 142(6): 1108-1116.

[46] Vinha, A. F., Ferreres, F., Silva, B. M., Valenta o, P., Goncüalves, A., Pereira, J. A., Oliveira, M. B. P. P., Seabra, R. M. and Andrade, P. B. (2005): Phenolic profile of portuguese olive fruits (Olea europaea $\mathrm{L}$.): influences of cultivar and geographical origin. Food Chemistry 89(4): 561-568.

[47] Walker, R. W., Mc Larty, D. G., Kitange, H. M., Whiting, D., Masuki, G., Mtasiwa, D. M., Machibya, H., Unwin, N. and Alberti, K. G. (2000): Stroke mortality in urban and rural Tanzania. Adult morbidity and mortality project. - Lancet 355(9216): 1684-1687.

[48] WHO. (2013): A global brief on Hypertension: silent killer, global public health crises (World Health Day 2013). - WHO, Geneva.

[49] Yoruk, O., Gur, F. O., Uyanik, H., Yasar, M., Mutlu, V., Altas, E., Baysal, E. and Taysi, S. (2010): Antioxidant Effects of Nigella sativa in the Treatment of Experimentally Induced Rhinosinusitis. - Macedonian Journal ofMedical Sciences 3(2): 132-137.

[50] Zaoui, A., Cherrah, Y., Mahassini, N., Alaoui, K., Amarouch, H., Hassar, M. (2002): Acute and chronic toxicity of Nigella sativa fixed oil. - Phytomedicine 9(1): 69-74. 


\section{APPENDIX}

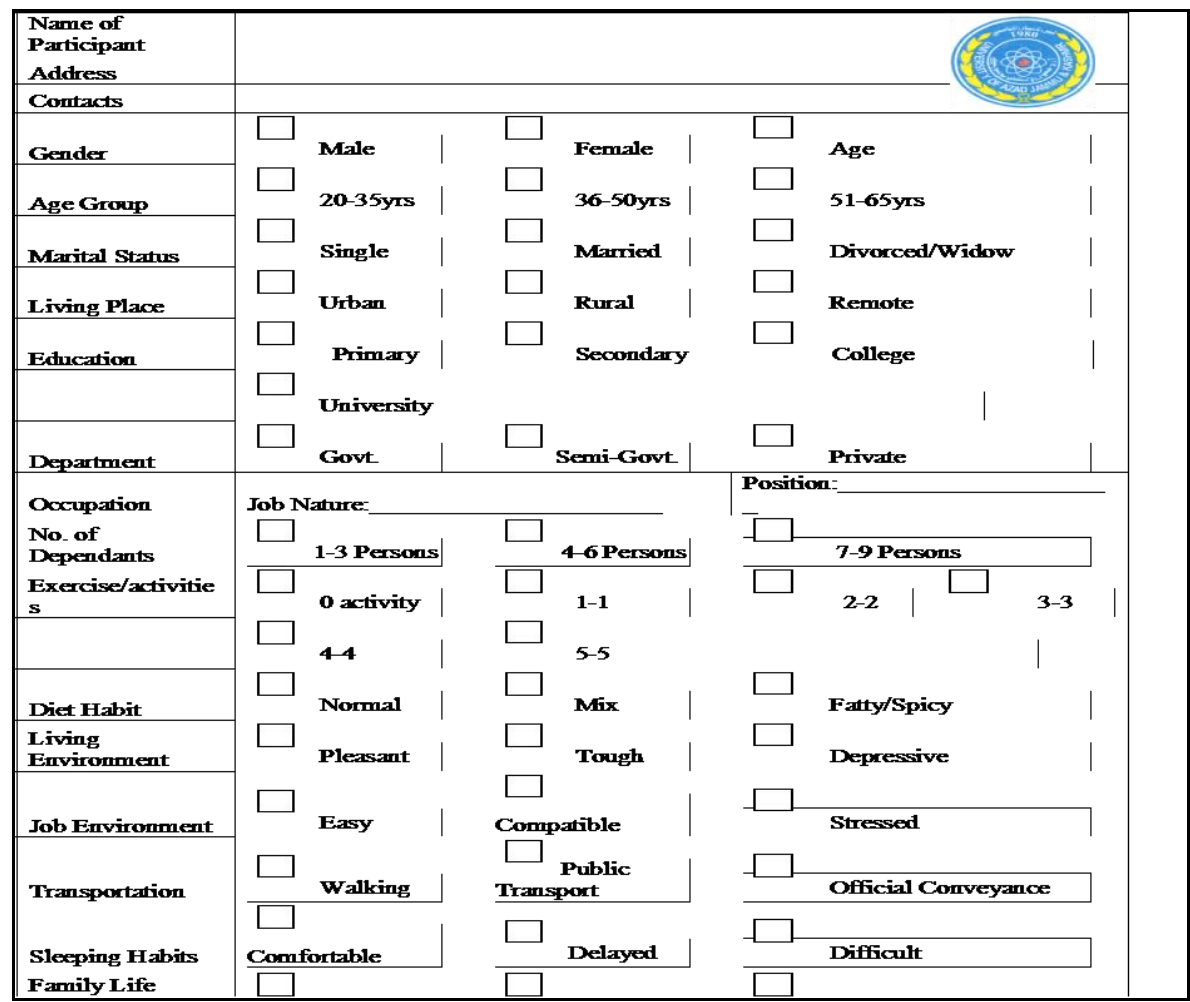

Supplementary Figure 1. Questionnaire used for the subjects in clinical studies

\section{Registration for the Clinical Studies}

I am explained all the benefits and outcomes of the treatment that will have to be given me during this clinical studies. I agreed voluntarily basis and promise to be loyal with all its treatment protocol.

ID:

Male or Female: Date of Birth:

Signature: Contact \#:

Witness:

Diagnosed Indications

Responsible Clinician

Name: Position: Tel\#: Date:__ Time:

Supplementary Figure 2. Proforma used for subjects consent participating in clinical study 


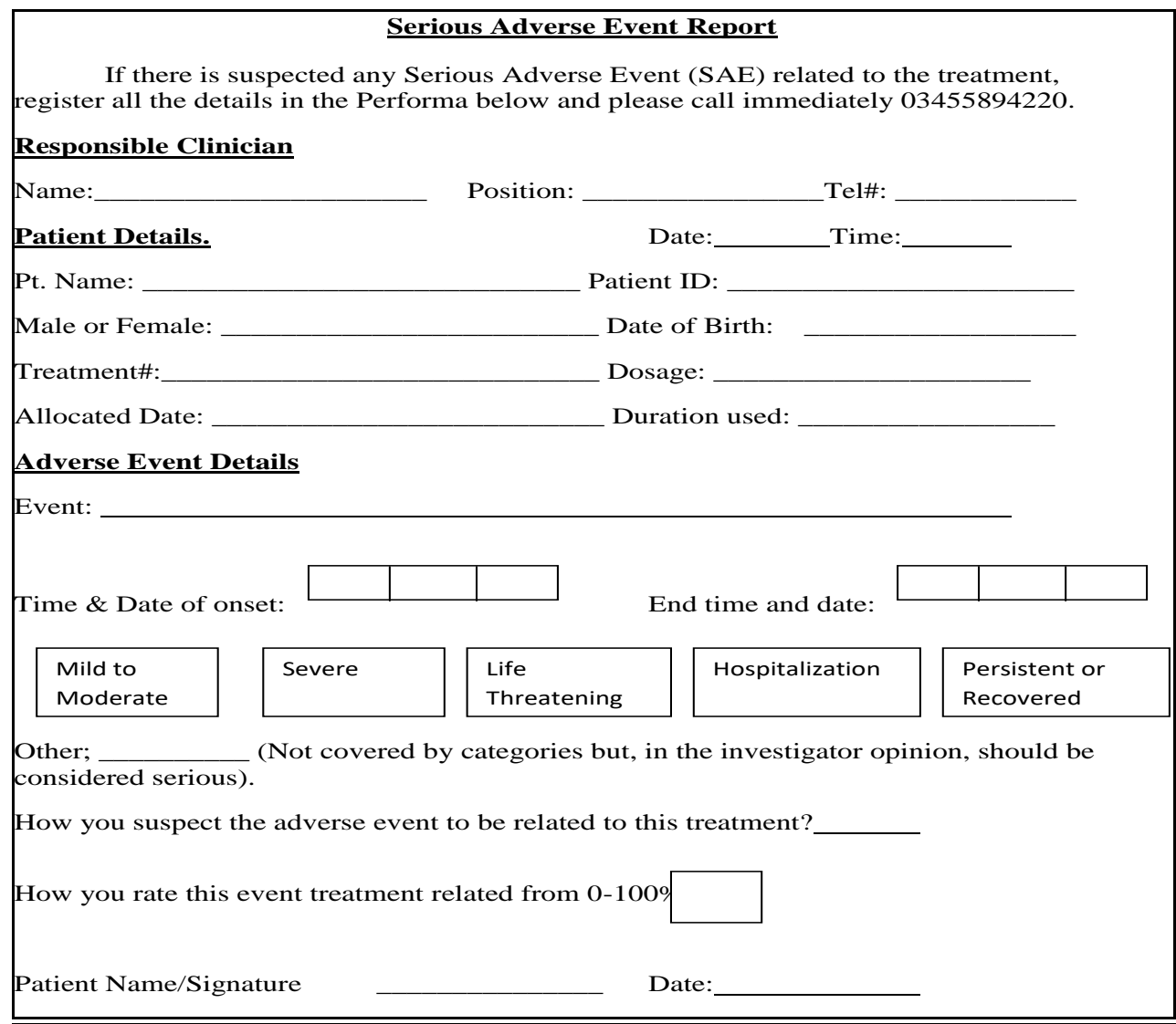

Supplementary Figure 3. Proforma used for subjects reporting serious adverse events

\begin{tabular}{|c|c|c|c|c|}
\hline \multicolumn{5}{|c|}{ Clinical Investigations } \\
\hline & & & & Date: \\
\hline \multirow{3}{*}{1} & & Sistolic & \multicolumn{2}{|l|}{ Diastolic: } \\
\hline & Blood Pressure: & Pofonoment & …....... & ..... \\
\hline & & \multicolumn{3}{|l|}{ (References) } \\
\hline \multirow[t]{5}{*}{2} & Lipid Profile: & Lower Limit & \multicolumn{2}{|c|}{ Upper Limit } \\
\hline & Cholesterol: & $3.6 \mathrm{mmol} / \mathrm{l}$ & \multicolumn{2}{|c|}{$6.5 \mathrm{mmol} / 1$} \\
\hline & $\begin{array}{l}\text { Triglyceride: } \\
\text {................. }\end{array}$ & $\leq 1.7 \mathrm{mmol} / 1$ & \multicolumn{2}{|c|}{$\leq 1.7 \mathrm{mmol} / 1$} \\
\hline & LDL: & $2 \mathrm{mmol} / \mathrm{l}$ & \multicolumn{2}{|c|}{$3.4 \mathrm{mmol} / 1$} \\
\hline & HDL: & $0.9 \mathrm{mmol} / \mathrm{l}$ & \multicolumn{2}{|c|}{$2.2 \mathrm{mmol} / 1$} \\
\hline \multirow[t]{7}{*}{3} & Serum Glucose: & & & \\
\hline & Random: & $6.6 \mathrm{mmol} / 1$ & \multicolumn{2}{|c|}{$10 \mathrm{mmol} / \mathrm{l}$} \\
\hline & 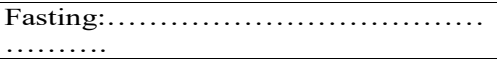 & $3.8 \mathrm{mmol} / 1$ & \multicolumn{2}{|c|}{$6.1 \mathrm{mmol} / 1$} \\
\hline & \multicolumn{4}{|l|}{$\begin{array}{l}\text { Creatnine } \\
\text { Clearance:.. }\end{array}$} \\
\hline & BMI: $\ldots \ldots \ldots \ldots \ldots \ldots \ldots \ldots \ldots \ldots \ldots \ldots \ldots \ldots \ldots \ldots \ldots \ldots \ldots$ & Weight: $\ldots \ldots \ldots$ & Waist:......... & Height:.... \\
\hline & \multicolumn{4}{|l|}{$\begin{array}{l}\text { Patient consent } \\
\text { Do you agree for clinical trial? }\end{array}$} \\
\hline & & & & Name \& Sig \\
\hline
\end{tabular}

Supplementary Figure 4. Proforma used for subjects clinical investigations 